Brit. J. vener. Dis. (1960), 36, 175.

\title{
AN IMIDAZOLE DERIVATIVE (FLAGYL) EFFECTIVE ORALLY IN VAGINAL TRICHOMONIASIS*
}

\author{
BY \\ R. R. WILLCOX \\ St. Mary's Hospital, London
}

The very large number of chemical, antibiotic, hormonal, and other substances prepared as powders, creams, ointments, and solutions and applied by various means in the local treatment of vaginal trichomoniasis is a striking testimony to the general ineffectiveness of them all. Recurrence rates of 30-50 per cent. after the ensuing menstrual period are commonplace. Such recurrences are considered due to residual trichomonads not reached by the vaginal medication, particularly in the urethra and para-urethral glands, from which re-infection of the vagina may occur, and from re-infection from the male consort who may harbour $T$. vaginalis in the urethra and prostate or in the sub-preputial sac. What is required is an effective drug which may be given systemically and which may also be used, if necessary, for the male partner.

The substances already tried have completely or almost completely disappointed. These have included arsenical and bismuth preparations, atebrin and other anti-malarial drugs, antibiotics (including penicillin, streptomycin, the broad-spectrum group, and the anti-fungal antibiotic trichomycin), and also aminitrozole-although claims had been advanced as to the usefulness of the latter two substances.

A new substance developed in France, and known as Flagyl (8823 R.P.) $\alpha-\beta$ hydroxyethyl-2-methyl-5 nitro-imidazole, holds considerable promise in the treatment of this troublesome condition. It is available in 200-mg. tablets for oral use, and in ordinary doses appears to be a relatively non-toxic drug (Cosar and Julou, 1959). Durel, Roiron, Siboulet, and Borel $(1959,1960)$ have reported upon its successful use in all of twelve male patients with urethral trichomoniasis and in sixteen of nineteen women with vaginal trichomoniasis-although in the latter series, local treatment with the same preparation was usually administered concurrently. The

* Received for publication July 18, 1960. present paper concerns the preliminary findings in forty women with vaginal trichomoniasis to whom only oral treatment was given.

\section{Material}

The average age of the forty women was $25.5 \mathrm{yrs}, 26$ being under $25 \mathrm{yrs}$ of age (extremes 17-53 yrs). Six were Negresses, fourteen were married, seven were pregnant, and three had passed the menopause. Fourteen of the patients had had 23 previous attacks of vaginal trichomoniasis, eight had had fourteen previous attacks of gonorrhoea, and two had had syphilis. Only fourteen had had no previous genital infection.

\section{Method}

Motile trichomonads were observed in wet specimens of the vaginal discharge in all cases before treatment. Ten patients were found to have gonorrhoea also, and this was treated with penicillin. The patients were given $200 \mathrm{mg}$. Flagyl three times a day for one week, without any local treatment. The course of treatment was completed by 32 patients, and eight took the tablets for 5 or 6 days.

\section{Results}

The drug was very well tolerated, no patient complaining of side-effects. The immediate results were spectacular; in the 34 patients followed, there were only two treatment failures $(5.9$ per cent.). One of these was a young pregnant woman who had previously had many forms of local treatment without success; trichomonads were found after 3 and 7 days of treatment and again later, even after further local treatment had been given. The other failure who was still showing trichomonads after one week, had the treatment continued for a further week; smears were negative at 7 days but positive again at 14 days. She was treated again for a further week and the smears were again negative at 3 and 7 days but there was a further recurrence at 21 days. On this occasion a 10-day course was given and the 
patient did not return for 30 days, when trichomonads were again found. The husband of this patient showed signs of a mild prostatitis but no trichomonads were demonstrated.

In addition to these two treatment failures, there have been six recurrences, five of which $(14 \cdot 7$ per cent. of those followed) occurred within the 3 months of planned observation, and one after 104 days. Three occurred at 21-24 days after the next monthly period and two occurred in pregnant women at 28 and 48 days respectively. Both of the treatment failures and all of the six relapses occurred in white women who had completed the full course of treatment. Four of the eight were single and four were married, and one of them was a prostitute. The male consorts of three were examined, but no trichomonads were found, though two had shreds in the urine and pus in the prostatic secretion.

There were also three cases of vaginitis (at 54, 56, and 70 days) in which trichomonads were not found, and two cases in which treatment was given for vaginal thrush at 15 and 60 days respectively.

The observations made after the initial course of therapy are summarized in Table I.

\section{TABLE I}

POST-TREATMENT OBSERVATIONS AFTER INITIAL TREATMENT OF FORTY PATIENTS WITH VAGINAL TRICHOMONIASIS USING FLAGYL (8823 R.P.)

\begin{tabular}{c|c|c|c}
\hline $\begin{array}{c}\text { Follow-up } \\
\text { (days) }\end{array}$ & $\begin{array}{c}\text { No. } \\
\text { Followed }\end{array}$ & \multicolumn{2}{|c}{ Observations } \\
\cline { 2 - 4 } & & Negative & Positive \\
\hline 0 & 40 & -9 & - \\
$1-3$ & 34 & 27 & $\frac{1}{3}$ \\
$4-7$ & 33 & 14 & $\frac{1}{8-14}$ \\
$15-21$ & 25 & 7 & 2 \\
$22-28$ & 21 & 7 & 2 \\
$29-60$ & 17 & 11 & 1 \\
$61-90$ & 11 & 7 & 10 \\
\hline Over 90 & 6 & 91 & \\
\hline Total & 40 & & \\
\hline
\end{tabular}

Thus, of 101 post-treatment observations made at periods of from 3 to over 90 days after treatment, positive readings were found in ten. These included two readings from one of the two treatment failures in which positive results were obtained both at 3 and at 7 days, and readings from one patient who had positive smears at 5 days but who subsequently had negative results up to 131 days of observation. As will be noted, trichomonads commonly disappeared from the smears as early as $\mathbf{3}$ days from therapy.

The overall results obtained with Flagyl are contrasted with earlier results obtained with trichomycin and aminitrozole (Table II).

The immediate failure rate with Flagyl was 5.9 per cent., compared with 100 per cent. with aminitrozole and 90 per cent. with trichomycin. It is not possible to calculate a relapse rate with the two latter substances, as in the two series described there was only one patient who apparently responded and who could therefore have relapsed.

\section{Summary}

(1) Forty patients with vaginal trichomoniasis have been treated with Flagyl (8823 R.P.) given as one 200-mg. tablet three times daily for 5-7 (usually 7) days without local treatment.

(2) No side-effects were noted and immediate results were spectacular; of 34 patients followed, there were only two (5.9 per cent.) immediate failures. Trichomonads disappeared temporarily from one of the failures when treatment was extended for 2 weeks. At the time of assessment there had been five relapses (14.7 per cent.) in the 90 days of post-treatment observation, and one after 104 days. Two failures occurred in pregnant women at 28 and 48 days respectively and three at 21 to 24 days following the next monthly period.

(3) Re-treatment of four failures also resulted in response, but further relapses occurred in three of them. Local treatment was given to two patients for vaginal thrush at 15 and 60 days respectively. There were also three cases of vaginitis, at 54, 56, and 70 days respectively, in which trichomonads were not found.

(4) It is evident that Flagyl (8823 R.P.) is a most promising drug for the treatment of trichomoniasis. The immediate failure rate of 5.9 per cent. contrasts markedly with the immediate failure rates of $90 \cdot 2$ 100 per cent. after the use of trichomycin and aminitrozole.

TABLE II

RESULTS OF ORAL THERAPY OF VAGINAL TRICHOMONIASIS

\begin{tabular}{|c|c|c|c|c|c|c|c|c|c|}
\hline Drug & & $\begin{array}{l}\text { Length of } \\
\text { Treatment } \\
\text { (days) }\end{array}$ & Dosage & $\begin{array}{l}\text { No. } \\
\text { Treated }\end{array}$ & $\begin{array}{l}\text { No. } \\
\text { Followed }\end{array}$ & Failures & $\begin{array}{l}\text { Relapse } \\
\text { within } \\
3 \text { mths }\end{array}$ & $\begin{array}{c}\text { Failure } \\
\text { Rate } \\
\text { (Per cent.) }\end{array}$ & $\begin{array}{c}\text { Relapse } \\
\text { Rate } \\
\text { (Per cent.) }\end{array}$ \\
\hline $\begin{array}{l}\text { Aminitrozole } \\
\text { Trichomycin } \\
\text { Flagyl (8823 R.P.) } \ldots\end{array}$ & $\begin{array}{l}\ldots \\
\cdots \\
\cdots\end{array}$ & $\begin{array}{l}6-14 \\
3-7 \\
5-7\end{array}$ & $\begin{array}{c}1 \cdot 8-4 \cdot 9 \mathrm{~g} . \\
400,000-1,800,000 \text { units } \\
3 \cdot 0-4 \cdot 2 \mathrm{~g} .\end{array}$ & $\begin{array}{l}13 \\
12 \\
40\end{array}$ & $\begin{array}{l}13 \\
11 \\
34\end{array}$ & $\begin{array}{r}13 \\
10 \\
2\end{array}$ & $\overline{5}$ & $\begin{array}{r}100 \cdot 0 \\
90.9 \\
5.9\end{array}$ & $\overline{14 \cdot 7}$ \\
\hline
\end{tabular}


(5) The optimal duration of treatment, the necessity for repeated courses, or the possible need for timing the treatment to coincide with the menses, and the need for treating the male consort simultaneously, can only be determined by extensive trials.

\section{REFERENCES}

Cosar, C., and Julou, L. (1959). Ann. Inst. Pasteur., 96, 238.

Durel, P., Roiron, V., Siboulet, A., and Borel, L. J. (1959). C.R. Soc.

- franc. Gynéc., 29,36.

Un dérivé de l'imidazole actif par voie orale dans la trichomoniase vaginale

Résumé

(1) Quarante malades atteints de trichomoniase vaginale furent traités par Flagyl (8823 R.P.), administré sous forme de comprimés de $200 \mathrm{mg}$. trois fois par jour pendant 5 à 7 jours (généralement 7) sans aucun traitement local.

(2) On n'observa pas de réactions secondaires et les résultats immédiats furent spectaculaires; sur 34 malades suivies, il n'y eit que deux $(5,9 \%)$ échecs immédiats. Les trichomonades disparurent temporairement dans un cas d'échec lorsque le traitement fut prolongé à 2 semaines. Au moment d'évaluation il y eut cinq rechutes $(14,7 \%)$ en dedans d'une période de 90 jours d'observation et une rechute après 104 jours. Deux des échecs survinrent chez des femmes enceintes au bout de 28 et 48 jours respectivement, et trois échecs 21 et 24 jours après la dernière période menstruelle.

(3) Un second traitement des quatre cas d'échec donna un bon résultat, mais chez trois d'entre eux se produisirent de nouvelles rechutes. Un traitement local fut administré à deux malades atteintes de moniliase vaginale le 15 -ème et le 60 -ème jour respectivement. Il y eut aussi trois cas de vaginite au bout de 54,56 et 70 jours respectivement, où on ne trouva pas de trichomonas.

(4) Il est évident que Flagyl (8823 R.P.) est un médicament plein de promesses pour le traitement de la trichomoniase. Le chiffre des échecs immédiats de 5,9 pour cent se détache nettement contre des chiffres obtenus avec l'emploi de la trichomycine ou de l'aminitrozole, donnant un taux d'échecs de 90,2 à 100 pour cent.

(5) La durée optima du traitement, la nécessité de répéter les cures ou de les ajuster aux temps de la menstruation, ainsi que le besoin de traiter l'époux, restent à determiner par des essais approfondis.

\section{ADDENDUM}

Since this paper was written, there has been one further relapse at 81 days. 